\title{
Editorial on the special issue "Empirical Analyses based on the German Family Panel (pairfam)"
}

\author{
Johannes Huinink
}

\section{Introduction}

The articles in this special issue present empirical analyses based on the data from the German Family Panel (pairfam). The study uses the acronym "pairfam" referring to its English title "Panel Analysis of Intimate Relationships and Family Dynamics." The articles provide example insights into the possibilities offered by empirical analyses using data of the first pairfam waves. They are thus not simple overviews, but deal with specific research issues referring to three of four focal themes of the pairfam panel which are of special interest for demographic research: intimate relationships, fertility and intergenerational relationships. In addition, a methodological article presents an analysis of high relevance for the design of the survey addressing factors that influence the willingness of third parties to participate in the survey - in this case the partners and parents of the anchors. The articles originate from the contexts of various disciplines in demographics, psychology and sociology.

The long-term design of the German Family Panel aims to contribute to improving the empirical basis of German and international research on dynamics of intimate relationships and family histories. It is funded by the German Research Foundation (DFG) as a long-term research project in the humanities and social sciences. The first panel wave was launched in 2008. Since then, the anchors from the pairfam sample are surveyed annually along with their partners, parents and children.

To prepare the methodological concept and contents, during the four years prior to the launch of the panel, special research questions dealing with intimate relationships and family dynamics have been investigated in nineteen research projects which were all part of a DFG priority programme. This programme also included a self-managed "mini panel" consisting of three waves, which served as the methodological test run for the pairfam study (Feldhaus/Huinink 2008). A number of notable scholars of relationship and family research from various disciplines participated in this initiative of socio-scientific family research, which was unique in its magnitude at the time. Without this broad-ranging cooperation, pairfam would probably never have materialised.

In May 2010, the data from the first wave of the German Family Panel were made available to the academic public for analyses. Since then, three panel waves have 
been published and documented. ${ }^{1}$ Therefore, meanwhile extensive data is available also enabling longitudinal analyses. The fourth wave of the panel will be delivered in 2013 and the fifth wave of pairfam is in the field at the moment (the end of 2012). A total of 14 panel waves are planned until the year 2022 in the context of the DFG funding scheme. Therefore, a long-term observation of relationship and family histories will be realised.

For a more detailed introduction to the design and data of the German Family Panel we refer to existing publications and documentation. The theoretical foundation, the research background and the details of the sample design are presented in Huinink et al. (2011). Extensive information is also accessible on the website of the project at www.pairfam.de. Among others, Technical Paper No. 1 can be found there, which documents the design, the field profile of the first three waves and important facts on the samples of the waves, including the response rates (Arránz Becker et al. 2012). In addition, a documentation of the questionnaires and variables of each wave, which are also part of the data releases, can be downloaded.

First, this editorial briefly introduces the study themes and the design of the German Family Panel. Some thoughts relevant to demographic research concerning challenges to relationship and family research, which the elaborate undertaking of pairfam aims to meet (cf. Huinink/Feldhaus 2009), follow. The editorial closes with a brief summary of the five articles of this special issue.

\section{The focal themes and the methodological design of the German Family Panel (pairfam)}

The German Family Panel was devised to provide data for studies concerning intimate relationship and family histories that go beyond traditional demographic analyses of the incidence and timing of biographical events that are related to intimate relationships or families and intergenerational relationships. Apart from relevant structural facts of couple and family dynamics it is intended to offer additional longitudinal information on subjective attitudes, situation assessments and intentions on which these events and social relationships are based. The survey programme of the panel has an interdisciplinary design. It combines theoretical as well as empirical research questions from socio-scientific and psychological family research. Although the survey programme aims to cover as many aspects of individual life courses as possible in the context of which relationship and family dynamics develop, the survey focuses on four themes. These will be briefly introduced with example references to the respective survey modules and selected studies published nationally and internationally over the past three years.

1 Nauck, Bernhard, Josef Brüderl, Johannes Huinink, and Sabine Walper. 2012: Beziehungs- und Familienpanel (pairfam). GESIS Datenarchiv, Köln. ZA5678 Datenfile Version 3.0.0, doi:10.4232/ pairfam.5678.3.0.0. 
Beforehand, two edited volumes with papers presented on pairfam user conferences concerning all four study themes shall be mentioned: Walper/Wendt (2010) and Brüderl et al. (2011).

1. Development and stability of intimate relationships

Information is collected on the previous relationship history, on partner search and the circumstances of beginning a partnership, on subjectively expected costs and benefits of an intimate relationship, on possible steps taken to institutionalise an intimate relationship, on couples' arrangements in everyday life and interaction of the partners, on the assessment of the relationship quality as well as on causes and consequences of separation.

Pairfam data has been used so far for studies in this research area dealing with the partner market and finding partners, the social interaction between partners, relationship quality and satisfaction, the development and stability of non-marital unions, the interrelation between couple dynamics and geographical mobility of the partners and with sexuality (cf. e.g. Arránz Becker 2012; Diener/Feldhaus 2011, Kopp et al. 2010, Lois 2012, Lois/Lois 2012, Rainer/Smith 2012, Perelli-Harris et al. 2012, Schmitz et al. 2011, Smith 2012, articles from the edited volumes cited above that are not listed individually, chapters of an edited volume on the comparison of partnerships in East- and West Germany in Huinink et al. 2012).

The first two articles in this special issue also deal with research questions concerning intimate relationships. The article by Franziska Schmal and Sabine Walper contributes new findings on the determinants of relationship quality making use of special characteristics of the pairfam design, while Jürgen Dorbritz and Robert Naderi investigate the development and stability of noncohabitating couple relationships in detail.

\section{Fertility intentions and reproductive behaviour}

Information is collected, for example, on the previous family history, the expected costs and benefits of parenthood and children, on fecundity and contraceptive behaviour, on the desire to have children and intentions to start or to extend a family, on factors influencing reproductive decisions and their implementation (timing and spacing of births), on effects of family-policy measures and on how people deal with anticipated consequences of parenthood. The main issues studied with pairfam data in this area of research are the explanation of fertility intentions and its realisation in different living arrangements, the analysis of couples' decision making on fertility, the significance of influences of the social network and potential effects of family-policy measures on fertility, the description of the diversity and change of familial living arrangements as well as life-course specific analyses of the development of different types of families. (cf. e.g.: Bauer/Kneipp 2012, Buhr/Huinink 2012, Feldhaus/Huinink 2011, Huttemann et al. 2012, Kotte/Ludwig 2011, Lois/Kopp 2011, Nauck/Tabuchi 2012, Perelli-Harris et al. 2010, Rüger et al. 2011, articles in the edited volumes cited above and in Huinink et al. 2012). 
The third article in this volume ties in with this research by examining the relationship between geographical mobility and family planning as well as starting a family, what has not been possible using previous data sets.

\section{Intergenerational relationships}

Here information has been surveyed on the expected costs and benefits of parent-child relationships, on the perceived quality of the relationship between children and parents or stepparents, on the kind and intensity of social interaction between them, on the extent of material and non-material support exchanged as well as various dimensions of transmission processes between generations. Not only the (step-) parents of the respondents, but also their grandparents are included.

Regarding this focal theme, analyses of typical constellations of intergenerational relationships are investigated, but also relationships that have not yet been in the focus of socio-scientific research have been addressed: relationships between stepchildren and stepparents, intergenerational relationships among individuals with migration background and behaviour-related, intergenerational transmission effects (cf. e.g. Baykara-Krumme et al. 2011, Klaus et al. 2012, Kotte/Ludwig 2011, chapters from the edited volumes cited above that are not listed individually).

The fourth article in this special issue is also dedicated to one type of intergenerational relationships that has not yet been studied in this detail before: the social relationship between grandchildren and their grandparents.

\section{Parenting and child development}

With regard to this focal theme information is surveyed, for example, on parenting objectives and the child-raising skills of parents, on parenting behaviour from the perspective of the parents and their children, on childcare provisions as well as on factors influencing child development processes.

Among other aspects, these data enable the observation of the chronological development of parent-child relationships over a long period of time and the investigation of effects of different conditions of everyday life and family relationships on the socialisation of the child in detail (cf. the articles by Reichle et al. and the editors in Walper/Wendt 2010).

In addition to data concerning these four focal themes, retrospective and present information is gathered on childhood experiences of the respondents, on their education and employment and on their geographical mobility. Further survey modules provide data, for example, on the household composition and living situation, on recreational behaviour, on additional social relationships (siblings, kin, social network), on the economic situation of the households of the respondents and their parents, on values (gender roles, family norms), the physical and psychological well-being (stress, depression, health, etc.) as well as selected personality traits (the "big five," etc.). 
The sample of the German Family Panel follows a cohort design. In the first wave, 12,401 male and female "anchors" from three birth cohorts have been surveyed. They were born in the years $1971-73,1981-83$ or 1991-93. The sample was drawn randomly from the population of members of these three cohorts living in Germany (registry office sample). It also contains people with foreign nationalities; however, participation in the survey requires that the anchors have sufficient German language skills to follow the interview. The high number of cases and the cohort design are intended to ensure that sufficient cases are available for more differentiated and age-sensitive longitudinal analyses. Specifically for comparative analyses between Eastern and Western Germany, it is possible to enhance the numbers of cases of the Eastern German sample with data from the panel survey "DemoDiff". Three waves were conducted by the Max Planck Institute of Demographic Research and it has been integrated from the fifth wave on into the sample of the German Family Panel (Kreyenfeld et al. 2012).

The panel surveys are conducted annually. The anchors are surveyed using a computer-aided personal interview (CAPI). A core set of questions is repeated each year. In addition, more detailed information concerning the focal themes are gathered every two years (follow-up modules) and some variables, such as personality traits, are surveyed at even greater intervals. This staggering ensures that with an interview length of one hour on average, the extent of the information gathered is considerable and there is additional space for selective follow-up modules.

Another design element of pairfam is the multi-actor approach. Information concerning relevant aspects is surveyed directly from important family members if the anchor approves. From the first survey wave on, the partners of the anchors are surveyed (written questionnaire), regardless of whether they live together in one household with the anchor or not. In this wave, a total of 3,743 partners took part in the survey. From the second wave on the (step-) parents are surveyed via a written questionnaire and the children of the anchors living in their household between the ages of 8 and 15 years orally. In the second wave, 5,015 parents and 862 children participated in the survey. When the anchors' children exceed the age of 15 , they are treated as new anchors.

The German Family Panel is already internationally well established today. The data, as the quoted literature shows, has already been used a number of times for international comparisons (cf. Perelli-Harris et al. 2010, 2012, Nauck/Tabuchi 2012). The aim is to intensify these international collaborations by producing equivalence files for data users in future in which data from different countries are matched with pairfam data.

\section{Challenges for demographic research of intimate relationships and family dynamics}

One justification for the establishment of the German Family Panel has been that from a contextual and methodological perspective such an extensive and costly data survey is necessary to make significant progress in empirical research on in- 
timate relationships and family dynamics. In the overview article on the pairfam project cited above, after an appraisal of the enormous progress achieved with longitudinal, life-course research in demographics, sociology, economics and psychology, it is posited:

"Yet, the complexity of linkages across the domains of family life and levels of analysis is not fully understood. The need for interdisciplinary cooperation has been increasingly recognised as a powerful tool to understand the complexity of family development and family dynamics in social, legal, economic, and cultural contexts and to shed light on the interplay between individual experiences, dispositions, behaviours, and well-being as they mutually influence each other in the context of family. ... The study [pairfam, $\mathrm{JH}$ ] is based on the notion that progress in family research strongly depends on sharing and conjoining expertise developed in the various disciplines, developing integrative theoretical perspectives, and employing longitudinal approaches with a large, representative data base and a broad array of information." (Huinink et al. 2011: 78).

Socio-demographic or psychological statistical analyses of the interdependence between family demographic events as well as their relation to the objective circumstances of individuals' lives have enormously improved our understanding of the dynamics of intimate and family relationships. However, their portrayal of personal motivations and decision processes on which the observed occurrences are based are inadequate. In order to prevent false conclusions and to examine relevant mechanisms more precisely and directly, this deficit, which has long been recognised, needs to be eliminated.

In Germany there are already numerous examples of research in family demography that focus on subjective attitudes, values and orientations. These include the DJI Family Survey (Bien/Marbach 2003), the Population Policy Acceptance Study (Höhn et al. 2008) and the Generations and Gender Survey (Naderi et al. 2009). Other examples could be mentioned. The studies are, however, not or only rudimentarily devised as panel surveys. They mainly allow descriptions or the analysis of correlative structures.

If we want to more precisely examine demographic processes related to intimate relationships and families as well as the personal decision processes they are based on and better identify causal effects, we have to conduct well set up panel surveys with as small intervals between the panel waves as possible. The methodological advantages of panel data for encountering problems of latent heterogeneity, for instance by using fixed effects or hybrid models, are only mentioned. These analysis methods are methodological standard today, which must be pursued in many cases in order to obtain coefficients as unbiased as possible in panel regressions. Regarding the substantive research questions, these methodological aids are not very helpful, since they contribute only very little to elucidating the actual mechanisms. That is why thematically focussed, very detailed panel studies are needed to fill the gap.

Only prospectively designed panel surveys allow us to gather not only retrospective or current information on structural circumstances and events, but also unbiased data on assessments regarding the current life situation and the mental state 
of the respondents. Purely retrospective surveys, which have undoubtedly had a major share in bringing forward demographic longitudinal research, do not hit the mark in this case. A retrospective survey of situation assessments, motivations and intentions is very error-prone, as psychological research shows (Schwarz/Sudman 1994). Therefore, the interest in a better understanding of the dynamics of intimate relationships and families as part of individually shaped if not always consciously steered life courses and methodological necessities suggest an intensification as well as a methodical realignment of panel analytic research. This is increasingly taken into account in existing panel surveys, such as the German Socio-Economic Panel Study (SOEP).

The German Family Panel, though, intends to take this issue into account in a more specific and extensive way (Huinink et al. 2011). It begins with the fact that, better than ever before, the pairfam data enable a more adequate description of the development of intimate relationships and familial living arrangements, of the everyday life in intimate relationships and families, and the interconnectedness of relationship and family developments with other spheres of life, such as employment or geographical mobility, over time. This includes in particular also a description of relationship and family relevant assessments, appraisals and motivations by the involved individuals that can change with time. The pairfam-based research, which was briefly mentioned in Chapter 2, shows that the data can fulfil this task. As we will see, the analyses in this special issue also make use of them.

A second circumstance, of which examples are also present in this special issue, refers to the consideration of intentions in the analysis of family demographic processes. One can examine how an intention in one sphere of life - for example, the plan to start a family - is influenced by personal circumstances and not only the behaviour itself. Longitudinally, we can identify incongruities between intention and behaviour in one sphere of life and we can analyse what causes it. We can also ask to which extent intentions in one sphere of life become relevant for intentions and activities in other spheres of life even before their possible realisation in order to change relevant conditions in the desired way. In this way, reciprocal effects between spheres of life are not only examined considering manifest actions like demographic transitions, for instance, but with regard to intentions. Therefore, the mechanisms on which this interdependency is based can be registered more precisely.

A third aspect that has to be stressed - and that plays a major role in previous analyses with the pairfam data and also in this special issue - is that of the advantages of the multi-actor design. This approach enables us to dispense with proxy information from the anchor. Proxy information is possibly considerably biased with regard to attitudes and assessments of other persons (partners, children, parents). The multi-actor design, which is continued in the panel in each wave, enables us to conduct dyadic analyses of couples or to examine the development of parent-child relationships during the child raising phase or later, when the children are older and have left home, from the respective perspective of parents and children.

A fourth issue that has not yet been approached extensively in previous analyses is also highly relevant in substantive and methodological terms. The cohort design 
of pairfam enables us to better identify (self-)selection effects of demographic behaviour and thus to trace important causal effects. Self-selection is a typical element of life-course processes. It is based on the fact that earlier experiences and circumstances in people's lives have an impact on current and future behaviour. Therefore, path dependencies have to be considered. Subjective preferences or intentions are primary candidates for explanatory factors in such self-selective processes since they influence the decisions of individuals and thereby possibly solidify further. An interesting example is what we called the "longitudinal third variable problem" (Huinink/Feldhaus 2009). Later behaviour in the life course, for example, the way women combine parenthood and employment, may be formed early on due to ideals of a good family life - like a traditional image of motherhood. In this case, it would be less the consequence of the current structural problems with regard to the reconciliation of work and family. This circumstance can only be empirically examined if we have the needed behaviour- and attitude-related information on this aspect of the person's life course over a sufficiently long period of time and from a sufficiently young age on. In a few years, the pairfam data allow to pursue these questions. Of course, it also cannot be excluded but is rather probable that orientations and attitudes change as the result of life events. They are adapted to attained circumstances before the dispositions in turn can again selectively influence ensuing actions. According to the dissonance theory, one should expect such processes. Sequences of selection and adaption processes in certain periods of time can also only be studied using suitable panel data. It is now already possible to study them using the data of the German Family Panel, but there are not yet any publications on this.

\section{$4 \quad$ Introduction to the articles of the special issue}

The first four articles in this special issue deal with aspects of the quality and development of intimate relationships, with the interrelationship between the intention to start a family, its realisation and geographical mobility and with the social relationship between grandparents and their grandchildren as a special type of intergenerational relationships that has received little attention in Germany in the past. In one way or another, they make specific use of the unique characteristics of the pairfam study design. The fifth article deals with one of these methodical characteristics by examining selectivity effects on the willingness of the partners and parents of anchors to take part in the survey in the context of the multi-actor design.

In their article, the psychologists Franziska Schmal and Sabine Walper look at determinants of successful intimate relationships and their consolidation. They focus on the question of whether the degree to which the two partners are able to satisfy their personal needs for autonomy and relatedness in their intimate relationship plays a role. For their empirical analyses they employ data from the first two pairfam waves, which were collected from the anchors and their partners. They restrict their study to the cohorts of those born between 1971-73 and 1981-83. Using a cluster analysis, they identify four typical groups of persons among the respondents and 
their partners who are characterised by different degrees of need fulfilment with regard to these two dimensions. The likelihood to belong to one of these types depends on the gender or the educational level. For example, men report more often of a lack of autonomy, while women more frequently consider both their needs for autonomy and for relatedness as fulfilled in the intimate relationship. The differences between the partners in an intimate relationship are also considerable, although the probability that partners belong to the same type is higher than expected if no correlation was assumed. In dyadic analyses, the authors estimate effects of autonomy and relatedness in the intimate relationship reported at the time of the first survey on the perceived relationship quality and future orientation in the second wave as well as on the probability of a consolidation of the intimate relationship between the two waves. Accordingly, the simultaneous fulfilment of both dimensions of needs on the part of the respondents contributes to a more positive assessment of the relationship quality and makes further institutionalisation of the intimate relationship more probable. It is also positive if the partners of the respondents report of greater autonomy and relatedness in the intimate relationship. However, the partner effects appear to be greater among women than among men.

In their article, the authors Jürgen Dorbritz and Robert Naderi deal with a specific type of relationships from a different perspective. They examine the development or stability of - as the authors call it - bilocal relationships in which the two partners live in two separate households. By making use of the possibilities of a detailed description of conjugal living arrangements, the authors pursue the question of what factors and circumstances influence the further develpoment of these relationships, which in the literature often also are called living-apart-together relationships. The authors, too, use data for the birth cohorts from 1971-73 and 1981-83 from the first two panel waves of pairfam. In an extensive description, using relevant indicators, they compare the LAT relationships with other types of conjugal living arrangements. According to them, non-cohabitating couples prove to be a quite heterogeneous group whose characteristics highly depend on the age group of the partners. Among the older age group, they differ more strongly from more institutionalised intimate relationships (cohabitating couples, marriages) than among the younger age group. The findings, as anticipated, indicate that partners living in relationships with separate households are more independent. Analyses of determinant factors of the future development (separation or starting to cohabit between the first two survey waves) confirm this assumption. In summary, the authors conclude from the results that a bilocal relationship in the older cohort can be considered a deliberately chosen living arrangement and that in their case it has less of a transitional character than among the younger cohort.

Effects of the commuting of women and men on their fertility intention and realisation are the subject of the article written by the sociologists Johannes Huinink and Michael Feldhaus. The authors use data from the first three waves of the German Family Panel. Their empirical analyses show how important it is to differentiate between intention and behaviour in the study of family development. For example, time-consuming commuting surprisingly does not adversely affect an intention of either men or women to have a child within the next two years (data from the first 
pairfam wave). In accordance with previous findings, however, its postponing effect on realising a planned birth can be proven. Not only in the cross-section, but also longitudinally it is demonstrated that the probability of having implemented a fertility intention that was expressed at the first panel wave two years later is considerably lower among women who commute for long distances than among women with no or only little commuting time. To start time-consuming commuting also appears to impede men's start into a family at least for the short term.

The article written by the sociologists Oliver Arránz-Becker and Anja Steinbach deals with the social relationship between grandparents and their grandchildren. Based on the model of intergenerational solidarity, the authors examine the factors which influence the strength of this relationship. They employ the multi-actor design by using data from the second panel wave, which was surveyed among the anchors, their parents and one of their children (child at an age of between 8 and 15 years). In the analysis, the authors form grandparent-grandchild dyads, for which comprehensive information is available. The authors demonstrate that not only the quality of the social relationship between grandparents and parents is important for the relationship to the grandchild (mediating position of the parents), but also the fact whether the grandparent lives in an intimate relationship or not. Grandmothers are more involved than grandfathers. For the former, however, health also plays a pivotal role. Another interesting finding is that the strength of the social relationship between grandparents and grandchildren is far greater in East than in West Germany. This indicates closer relatedness in the generational structure in East Germany. This finding conforms to the also proven relevance of familial value orientations of grandparents.

The final article, written by the sociologists Jette Schröder, Laura Castiglioni, Josef Brüderl and Ulrich Krieger, deals with a methodical question that plays an important role in the multi-actor design. Does the relationship quality of the anchor to a third person, in this case the partner or the parents, have an effect on the participation of this person in the survey? If such effects exist, the subsample with cases where a partner or parent interview has been realised is selective. The analyses use the data from the first and second panel wave of pairfam, whereby the youngest cohort is again excluded. With regard to the partner interview, surprisingly no significant effects of the indicators of the relationship quality on the participation probability could be ascertained. However, the degree of the institutionalisation of the intimate relationship, which was also taken into account, was of great relevance. Participation by parents of the anchors appears to be more strongly selectively biased. One of the indicators of the relationship quality, i.e. conflict frequency, is correlated with a lower participation probability. The perceived appreciation of the anchor by the parent as well as the contact frequency leads to a greater participation probability by the parent. Other effects could also be ascertained in both analyses. In the discussion of the results, the authors refer to the fact that the selectivity identified in the analyses can lead to biased results in other analyses, which can, however, be methodically countered in various ways. 


\section{References}

Arránz Becker, Oliver 2012: Effects of similarity in life goals, values, and personality on relationship satisfaction and stability: Findings from a two-wave panel study. In: Personal Relationships [doi: 10.1111/j.1475-6811.2012.01417.x].

Arránz Becker, Oliver et al. 2012: The German Family Panel: Study Design and Cumulated Field Report (Waves 1 to 3). Pairfam Technical Paper No. 1. Chemnitz.

Bauer, Gerrit; Kneip Thorsten 2012: Fertility From a Couple Perspective: A Test of Competing Decision Rules on Proceptive Behaviour. In: European Sociological Revie [doi: 10.1093/esr/jcr095].

Baykara-Krumme, Helen; Klaus, Daniela; Steinbach, Anja 2011: Eltern-Kind-Beziehungen in Einwandererfamilien aus der Türkei. In: Aus Politik und Zeitgeschichte 43: 42-49.

Bien, Walter; Marbach, Jan (Eds.) 2003: Partnerschaft und Familiengründung - Ergebnisse der dritten Welle des Familiensurvey. Wiesbaden: Verlag für Sozialwissenschaften.

Brüderl, Josef; Castiglioni, Laura; Schumann, Nina (Eds.) 2011: Partnerschaft, Fertilität und intergenerationale Beziehungen. Ergebnisse der ersten Welle des Beziehungsund Familienpanels. Würzburg: Ergon Verlag.

Buhr, Petra; Huinink Johannes 2012: Die Bedeutung familienpolitischer Maßnahmen für die Entscheidung zum Kind. In: Zeitschrift für Sozialreform 58: 315-341.

Diener, Katharina; Feldhaus, Michael 2011: 'Hartz' oder Herz? Hartz IV und die Intention zum Zusammenziehen in Partnerschaften. In: Zeitschrift für Sozialreform 57: 199-220.

Feldhaus, Michael; Huinink, Johannes (Eds.) 2008: Neuere Entwicklungen in der Beziehungs- und Familienforschung. Vorstudien zum Beziehungs- und Familienentwicklungspanel (pairfam). Würzburg: Ergon Verlag.

Feldhaus, Michael; Huinink, Johannes 2011: Multiple Elternschaften in Deutschland eine Analyse zur Vielfalt von Elternschaft in Folgepartnerschaften. In: Schwab, Dieter; Vaskovics, Laszlo A. (Eds.): Pluralisierung der Elternschaft und Kindschaft. Zeitschrift für Familienforschung, Sonderheft 8. Leverkusen: Verlag Barbara Budrich: 77-104.

Höhn, Charlotte; Avramov, Dragana; Kotowska, Irena (Eds.) 2008: People, Population Change and Policies. Lessons from the Population Policy Acceptance Study. Volume 1: Family Change. Dordrecht: Springer.

Huinink, Johannes; Feldhaus, Michael 2009: Family Research from the Life Course Perspective. In: International Sociology 24: 299-324.

Huinink, Johannes et al. 2011: Panel Analysis of Intimate Relationships and Family Dynamics (pairfam): Framework and design. In: Zeitschrift für Familienforschung 23: 77-101.

Huinink, Johannes; Kreyenfeld; Michaela; Trappe, Heike (Eds.) 2012: Familie und Partnerschaft in Ost- und Westdeutschland: Ähnlich und doch immer noch anders. Zeitschrift für Familienforschung, Sonderheft 9. Leverkusen: Verlag Barbara Budrich.

Hutteman, Roos; Bleidorn, Wiebke; Penke, Lars; Denissen, Jaap J. A. 2012: It Takes Two: A Longitudinal Dyadic Study on Predictors of Fertility Outcomes. In: Journal of Personality [doi: 10.1111/jopy.12006].

Klaus, Daniela; Nauck, Bernhard; Steinbach, Anja 2012: Relationships to stepfathers and biological fathers in adulthood: Complementary, substitutional, or neglected? In: Advances in Life Course Research 17: 156-167. 
Kopp, Johannes; Lois, Daniel; Kunz, Christina; Arránz Becker, Oliver 2010: Verliebt, verlobt, verheiratet. Institutionalisierungsprozesse in Partnerschaften. Wiesbaden: VSVerlag für Sozialwissenschaften.

Kotte, Markus; Ludwig, Volker 2011: Intergenerational transmission of fertility intentions and behaviour in Germany: The role of contagion. In: Vienna Yearbook of Population Research 9: 207-226.

Kreyenfeld, Michaela; Huinink, Johannes; Trappe, Heike; Walke, Reiner 2012: DemoDiff: A Dataset for the Study of Family Change in Eastern (and Western) Germany. In: Schmollers Jahrbuch 132: 1-8.

Lois, Nadia 2012: "Living apart together": Sechs Typen einer heterogenen Lebensform. In: Zeitschrift für Familienforschung 24: 247-268.

Lois, Daniel; Kopp, Johannes 2011: Elternschaftskonstellationen bei Alleinerziehenden. In: Schwab, Dieter; Vaskovics, Laszlo A. (Eds.): Pluralisierung der Elternschaft und Kindschaft. Zeitschrift für Familienforschung, Sonderheft 8. Leverkusen: Verlag Barbara Budrich: 59-76.

Lois, Daniel; Lois, Nadia 2012: "Living apart together" - eine dauerhafte Alternative? Zur Bedeutung von beruflichen Lagen und Partnerschaftsbildern für das Leben in getrennten Haushalten. In: Soziale Welt 63: 117-140.

Naderi, Robert; Dorbritz, Jürgen; Ruckdeschel, Kerstin 2009: Einleitung. Der Generations and Gender Survey in Deutschland: Zielsetzung, Verortung, Einschränkungen und Potenziale. In: Zeitschrift für Bevölkerungswissenschaft 34,1-2: 5-30.

Nauck, Bernhard; Tabuchi, Rokuro 2012: One or two pathways to individual modernity? The effects of education on family formation among women in Japan and Germany. In: Vienna Yearbook of Population Research 10: 49-76.

Perelli-Harris, Brienna et al. 2010: The educational gradient of childbearing within cohabitation in Europe. In: Population and Development Review 36: 775-801.

Perelli-Harris, Brienna et al. 2012: Changes in union status during the transition to parenthood in eleven European countries, 1970s to early 2000s. In: Population Studies 66: 167-182.

Rainer, Helmut; Smith lan 2012: Education, Communication and Wellbeing: An Application to Sexual Satisfaction. In: Kyklos 65: 581-598.

Reichle, Barbara; Franiek, Sabine; Dette-Hagenmeyer, Dorothea 2010: Frühe Sozialisation und Erziehung in der Familie: Konfliktbewältigung in der Elternpartnerschaft, Erziehungsstil und das Sozialverhalten angehöriger Kinder In: Walper, Sabine; Wendt, Eva-Verena (Eds.): Partnerschaften und die Beziehungen zu Eltern und Kindern. Befunde zur Beziehungs- und Familienentwicklung in Deutschland. Würzburg: Ergon Verlag: 241-267.

Rüger, Heiko; Feldhaus Michael; Becker, Katharina S.; Schlegel, Monika 2011: Zirkuläre berufsbezogene Mobilität in Deutschland: Vergleichende Analysen mit zwei repräsentativen Surveys zu Formen, Verbreitung und Relevanz im Kontext der Partnerschafts- und Familienentwicklung. In: Comparative Population Studies - Zeitschrift für Bevölkerungswissenschaft 36,1: 193-220.

Schmitz, Andreas; Sachse-Thürer, Susann; Zillmann, Doreen; Blossfeld, Hans-Peter 2011: Myths and facts about online mate choice: Contemporary beliefs and empirical findings. In: Zeitschrift für Familienforschung 23: 358-381.

Schwarz, Norbert; Sudman, Seymore 1994: Autobiographical memory and the validity of retrospective reports. New York: Springer Verlag. 
Smith, lan 2012: Reinterpreting the economics of extramarital affairs. In: Review of Economics of the Household 10: 319-343.

Walper, Sabine; Wendt, Eva-Verena (Eds.) 2010: Partnerschaften und die Beziehungen zu Eltern und Kindern. Befunde zur Beziehungs- und Familienentwicklung in Deutschland. Würzburg: Ergon Verlag.

Walper, Sabine; Wendt, Eva-Verena 2010: Partnerschaften und die Beziehungen zu Eltern und Kindern. Eine Einführung. In: Walper, Sabine; Wendt, Eva-Verena (Eds.): Partnerschaften und die Beziehungen zu Eltern und Kindern. Befunde zur Beziehungs- und Familienentwicklung in Deutschland. Würzburg: Ergon Verlag: 7-34.

Prof. Dr. Johannes Huinink ( $\triangle)$. Universität Bremen, Institut für empirische und angewandte Soziologie (EMPAS), Bremen, Germany.

E-Mail: huinink@empas.uni-bremen.de, URL: http://www.soziologie.uni-bremen.de 


\section{Comparative Population Studies - Zeitschrift für Bevölkerungswissenschaft}

wWw.comparativepopulationstudies.de

ISSN: 1869-8980 (Print) - 1869-8999 (Internet)

Published by / Herausgegeben von

Prof. Dr. Norbert F. Schneider

Federal Institute for Population Research

D-65180 Wiesbaden / Germany

Managing Editor /

Verantwortlicher Redakteur

Frank Swiaczny

Editorial Assistant /

Redaktionsassistenz

Katrin Schiefer

Language \& Copy Editor (English) /

Lektorat \& Übersetzungen (englisch)

Amelie Franke

Copy Editor (German) /

Lektorat (deutsch)

Dr. Evelyn Grünheid

\section{Layout / Satz}

Beatriz Feiler-Fuchs

E-mail: cpos@bib.bund.de

\author{
Scientific Advisory Board / \\ Wissenschaftlicher Beirat \\ Jürgen Dorbritz (Wiesbaden) \\ Paul Gans (Mannheim) \\ Johannes Huinink (Bremen) \\ Marc Luy (Wien) \\ Clara H. Mulder (Groningen) \\ Notburga Ott (Bochum) \\ Peter Preisendörfer (Mainz)
}

\section{Board of Reviewers / Gutachterbeirat} Martin Abraham (Erlangen) Laura Bernardi (Lausanne) Hansjörg Bucher (Bonn) Claudia Diehl (Göttingen) Andreas Diekmann (Zürich) Gabriele Doblhammer-Reiter (Rostock) Henriette Engelhardt-Wölfler (Bamberg) E.-Jürgen Flöthmann (Bielefeld) Alexia Fürnkranz-Prskawetz (Wien) Beat Fux (Zürich) Joshua Goldstein (Rostock) Karsten Hank (Köln) Sonja Haug (Regensburg) Franz-Josef Kemper (Berlin) † Michaela Kreyenfeld (Rostock) Aart C. Liefbroer (Den Haag) Kurt Lüscher (Konstanz) Dimiter Philipov (Wien) Tomáš Sobotka (Wien) Heike Trappe (Rostock) 